\title{
Factors Determining Job Satisfaction of Early Childhood Teachers
}

\author{
Shelina Bhamani \\ Faculty, Department of Education \\ Institute of Business Management (IoBM)
}

\begin{abstract}
Job satisfaction of teachers has recently demonstrated a great interest within educational researchers. However, little work has been done to explore this phenomenon in Pakistan. Therefore, the current study attempts to explore factors that determine job satisfaction of teachers teaching in early childhood classes in Karachi, Pakistan.It was hypothesized that after the literature review there will be a significant difference in job satisfaction between teachersrelevant to their academic qualification, and salary range. Moreover, it is generally expected that there is a relation between overall job satisfaction with nine factors viz. pay, promotion, supervision, fringe benefits, contingent rewards, operating conditions, coworkers, nature of work and communication. A sample of 133 teachers from early childhood settings was recruited for the study. The Job Satisfaction Survey (JSS; Spector, P., 1994) was administered to measure the factors that predict job satisfaction of the teachers. While, the data for the study was analyzed using two statistical tests: factor analysis of maximum likelihood and varimax rotation was used to explore the factors that determine job satisfaction and t-test deployed to explore the qualification, experience and salary differences. Results of the study suggest that the factors that determine job satisfaction in the study sample are (from highest to lowest) supervision, coworkers, promotion, continuous rewards, nature of work, pay, fringe benefits, communication and operational conditions.Furthermore, the data reveals no significant difference in the job satisfaction with regard to qualification and salary variables of the sample.
\end{abstract}

Keywords: teachers job satisfaction, teaching in early years, pay, promotion, supervision, coworkers, and communication

\section{Introduction and Literature Review}

The education system of Pakistan is facing innumerous challenges. Government and private sector aim to advance the quality of teaching and learning and have introduced initiatives that facilitate quality teaching and learning practices in the schools. These efforts aim to workn for quality assurance and focus hugely developingteachers' capacity to participate constructively in quality improvement. However, increasingly growing concerns about teachers' lack of motivation, constant turnovers, and lack of sustainable quality staff have been a spotlight for educational researchers in Pakistan to explore this phenomenon.

The relevance of teachers' job satisfaction is vital for a long term growth and development of any educational system around the world. Although considerable research has been devoted to study factors that determine teachers' job satisfaction there is a growing need to explore this phenomenon further to facilitate understanding in diverse contexts.

Job satisfaction, as defined in a range ofliteraturesis a positive and constructive perception or feeling of a person towards their job. It has also been referredto as a state of mind of an individual and how individuals experience their work lives. Job satisfaction can also be determined as a relationship between the work and the individual.

Furthermore, as stated by Adeyinka, Ayeni \& Popoola in 2007 "Job satisfaction is often determined by how well outcomes meet or exceedexpectations. For instance, if organization participants feel that they are working muchharder than others in the department but are receiving fewer rewards they willprobably have a negative attitudes towards the work, the boss and thier coworkers (p.4)".

In theory, job satisfaction in various research studies has been viewed from the perspectives presented by Maslow and Herzberg in their theories. Herzberg's as cited in Gawal (1997) has "constructed a twodimensional paradigm of factors affecting people's attitudes about work. He concluded that such factors viz. company policy, supervision, interpersonal relations, working conditions, and salary are hygiene factors rather than motivators. According to the theory, the absence of hygiene factors can create job dissatisfaction, but their presence does not motivate or create satisfaction (p.1)". There are number ofdeterminants of job satisfaction of individuals and they vary from context to context and from person to person.

Job satisfaction can be influenced with the wide range of factors and a few of them relate to pay scale, promotion, professional development, individual commitment to the organization, relationship with coworkers, 
supervision and mentoring provision (Akinboye, 2000; Akinboye, 2001; Opkara, 2002 \& Spector, 1985). Furthermore, the demography of each individual also has been reported as a predictor of the job satisfaction.

Wallace's study has widely focused on the implication of exploring factors that determine teachers' job satisfaction and asserts educational organizations and ministries to give respect to these rising needs. Many investigators have accentuated on teachers' retention and their research studies have shown a significant correlation between teachers' job satisfaction with teachers' turn over.

Teachers in various urban settings were found leaving the teaching profession and moving to other professions within the first five years of their career (Hammond, 2003; Wiebke \& Bardin, 2009). Consequently, it is noteworthy to inspect the factors predicting teachers' job satisfaction to retain quality staff in educational organizations.

Several research studies have shown educational qualification impacts job satisfaction to a higher degree. Raydon \& Chavelier's (2002)choosing 15000 sample surveyed variables that impact job satisfaction. The results of the study have shown a significant correlation of higher level of academic degrees with job satisfaction. Whereas, Bannerjee and Perrucci (2010) in their study have argued of sex and race having no impact but have highlighted the impact of co-workers relation on the overall job satisfaction.

Amongst the studies that investigate the factors influencing job satisfaction of teachersmany have attributed various factors that are directly associated with the overall job satisfaction. Bishey's (1996) study with the sample of 50 teachers has argued that the involvement of the teachers in co-curricular activities in the school have predicted their higher satisfaction. Remuneration has always been considered as the most influencing factor in job satisfaction. Kim and Loadman have in their study investigateddeterminants of job satisfaction and have found salary statistically significant predicator.

Furguson, Forst \& Hall (2012) in their study recruited 566 teachers from universities and have explored factors determining teachers' anxiety, depression and job satisfaction. The study postulates that workload and students' behaviour as positive predicators of job satisfaction and have reported stress and anxiety also being positively associated with job satisfaction. Likewise, Ali (2007) has conducted a similar study in NWFP of 212 teachers using job satisfaction survey and hasexplored the level of job satisfaction amongst the teachers. The study results indicated 1) high level of dissatisfaction amongst teachers with regard to promotions, 2) moderate level of dissatisfaction in respect off pay, fringe benefits, and contingent rewards while 3) moderate level of satisfaction with operating conditions, coworkers, nature of work and communication.

Teachers' job satisfaction has direct influence on their work performance. The sources that predict teachers' job satisfaction influence their teaching quality ultimately. This has been viewed consistent in the research studies in the past. Sargent \& Hamman in 2005 have reported a research study and have investigated three factors that are associated with teachers' job satisfaction and they are community factors, school environment and teacher characteristics. The results in the study illustrated a bivariate relationship between the variables of school building conditions, economic resources availability and provision of instructional working hours.

Schroffel has studied the factor of supervision closely and its effect on job satisfaction. In the research study, the researcher has examined 84 professionally trained workers and has explored the phenomenon of quality supervision and its implication on the job satisfaction. The results of the study have shown higher job satisfaction amongst the workers who were satisfied with the qualityof supervision provided,

Many studies have indicated a direct correlation of the teamwork and overall job satisfaction. It is vital to understand the team dynamics and how it impacts employees at work. Hence, a study carried out by Griffin, Pattarson, \& West has given a dimension of teamwork and how the role of supervision impacts overall job satisfaction. The study was administered on a sample of 4,708 employees. The results of the study indicated high correlation between the teamwork and job satisfaction.

Khan (n.d) has conducted an extensive review of the literature on "teachers' job satisfaction and incentives". Gill \& Ahmed (2009) have studied 110 university teachers to investigate effects of working conditions, pay benefits, and relationship with the coworkers. The study has shown positive significance relation between the variables. Likewise, Latif, Sohail \& Shehzab (2011) have carried out a comparative study on public and private college teachers on the job satisfaction. Their study has discoveredpublic college teachers to be more satisfied than the private sector college teachers.

Similarly, there are several studies conducted in Pakistan to explore the factors relevant to the job satisfaction of the teachers however there is a lack of study that focus on the job satisfaction of the teachers in early years setting. Hence, this research study intends to explore factors that predict job satisfaction of the early childhood teachers. Constant with the view, the subsequent research questions are addressed in this study:

- What are the factors that predict job satisfaction of the teachers in early childhood ?

- Is there a difference between the teachers' job satisfaction with relevance to their qualification and salary?

- Is there any relationship between overall job satisfaction with pay, promotion, supervision, fringe benefits, contingent rewards, operating conditions, coworkers, nature of work, and communication? 


\begin{abstract}
II. Method
Participants

The non-probability purposive sampling was employed to select the teachers for this study. Teachers from Karachi, Pakistan were chosen to participate in the study. A total of 133 teachers were recruited (see Table 1 for demographics). Academic qualification of the teachers appeared in two categoriesie. Bachelors (69.9\%) and masters $(30.1 \%)$. Respondents ranged in experiences from less than six years $(61.7 \%)$ to more than six years $(38.3 \%)$. The salary of the respondents varied from less than twenty thousand rupees $(\$ 220)(71.4 \%)$ and more than twenty thousand rupees $(28.6 \%)$
\end{abstract}

\title{
Measures
}

The research tool for the study was divided into two sections. Section one consisted a detailed demographic information Performa intended to explore gender, age, qualification, years of experience, class of teaching, salary range, and working hours. Section two consisted ofJobSatisfaction Survey (JSS; Spector, P., 1994)with an internal reliabilityof Cronbach's Alpha (.751) consisted of 36 items followed by 6-point response category scale (Agree very much $=6$, Agree moderately $=5$, Agree slightly $=4$, Disagree slightly $=3$, Disagree moderately $=3$, Disagree very much $=4$ ). The scale comprised of nine sub-scales Pay, Promotion, Supervision, Fringe Benefits, Contingent Rewards (performance based rewards), Operating Procedures (required rules and procedures), Coworkers, Nature of Work, and Communication.

\section{Procedure}

The informed consent form and questionnaire was given to the participants, upon receiving their consent to participate.. The participants were asked to complete the questionnaire manually. The forms were then coded for the data entry processes and data was entered and analyzed using Statistical Package for Social Sciences (SPSS)Version 20. Factor loading was used to explore the factors that determine job satisfaction; Ttest was used to explore the differences between the samples, and Pearson's correlation to explore the relationship between the variables.

\section{Results}

The data analysis focused on exploring factors that determine job satisfaction. Factor analysis was subjected to the data using SPSS. The extraction method of maximum likelihood and varimax rotation was employed for the factor loading. The results of the analysis indicated seven factors with eagenvalues greater than 0.4. Hence, factors which had more than 0.4 considered appropriate for reporting (see Table 2). The first factor, (Factor I), labeled "Fringe Benefits" accounted for $44.5 \%$ of the variance $(\mathrm{M}=13.7, \mathrm{SD}=3.4$ ) and had a coefficient of variance of $25 \%$. The second factor, (Factor II), labeled "Pay" accounted for $46.4 \%$ of the variance $(M=14.11, \mathrm{SD}=3.4)$ and had a coefficient of variance of $24.5 \%$. The third factor, (Factor III), labeled "Nature of Work" accounted for $46.5 \%$ of the variance $(\mathrm{M}=19.8, \mathrm{SD}=3.6)$ and had a coefficient of variance of $18.9 \%$. The fourth factor, (Factor IV), labeled "Continuous Rewards" accounted for $49.3 \%$ of the variance $(\mathrm{M}=$ $14.4, \mathrm{SD}=3.9$ ) and had a coefficient of variance of $27.1 \%$. The fifth factor, (Factor V), labeled "Promotion" accounted for $52.7 \%$ of the variance $(\mathrm{M}=14.3, \mathrm{SD}=3.4)$ and had a coefficient of variance of $24 \%$. The sixth factor, (Factor VI), labeled "Coworkers" accounted for $54.3 \%$ of the variance $(\mathrm{M}=18, \mathrm{SD}=3.1$ ) and had a coefficient of variance of $17.5 \%$. The seventh factor, (Factor VII), labeled "Supervision" accounted for $63.8 \%$ of the variance $(M=18.1, S D=3.5)$ and had a coefficient of variance of $19.7 \%$.

An independent-samples t-test was conducted to compare Job Satisfaction of the teachers having masters' degree and the teachers having bachelors' degree. There was no significant difference found between the teachers who have masters'degree $(M=138.5, \mathrm{SD}=16.3)$ and teachers with bachelors' degree $(\mathrm{M}=139, \mathrm{SD}=$ $17.1) ; \mathrm{t}=.173, \mathrm{p}>0.5$.

Likewise, an independent-samples t-test was conducted to compare Job Satisfaction of the teachers having more than twenty thousand salary and the teachers having less than twenty thousand salaries. There was no significant difference found between the teachers who had higher salary $(\mathrm{M}=141, \mathrm{SD}=16.2)$ and teachers having lower salary $(\mathrm{M}=138, \mathrm{SD}=17.1) ; \mathrm{t}=.-.925, \mathrm{p}>0.5$.

In addition to it, Pearson Correlation was administered to explore the relationship between overall job satisfaction with pay, promotion, supervision, fringe benefits, contingent rewards, operating conditions, coworkers, nature of work, and communication. Results of the correlation indicate that the overall job satisfaction is associated with pay $(\mathrm{r}=.552, \mathrm{p}<.001)$, promotion $(\mathrm{r}=.411, \mathrm{p}<.001)$, supervision $(\mathrm{r}=.687, \mathrm{p}<$ $.001)$, fringe benefits $(\mathrm{r}=.571, \mathrm{p}<.001)$, contingent rewards $(\mathrm{r}=.655, \mathrm{p}<.001)$, operating conditions $(\mathrm{r}=.424$, $\mathrm{p}<.001)$, coworkers $(\mathrm{r}=.462, \mathrm{p}<.001)$, nature of work $(\mathrm{r}=.601, \mathrm{p}<.001)$ and communication $(\mathrm{r}=.557, \mathrm{p}<$ 
.001). The analysis (Table 4) revealed that there is a statistically significant relation between the overall job satisfaction and all nine facets of job satisfaction.

The data provided few evidences of the difference in scores but no significant difference and hence the null hypothesis is rejected and it can be concluded that there is no difference between more qualified teachers and less qualified teachers: high salaried teachers and low salaried teachers in regard to job satisfaction. Furthermore, there is a statistically significant association between the overall job satisfaction with pay, promotion, supervision, fringe benefits, contingent rewards, operating conditions, coworkers, nature of work, and communication.

\section{Discussion}

The major aim of the study was to explore the factors that predict job satisfaction. The factors that emerged most important for job satisfaction are promotion, coworkers and supervision. Researches in the past have indicated a statistically significant correlation of the promotion with the overall job satisfaction.

Koasteas's study has investigated promotion and its impact on the job satisfaction; the results of the study have indicated higher job satisfaction in the employees who believed in receiving promotion from their employers. Likes, the other research studies have indicated significant impact of higher promotion on job satisfaction although the study has argued its sustainability in the longer run (Hammermesh, 2001; Koasteas, 2009; \& Stutzer, 2004).In Pakistani context teachers are amongst lowest paid workers and with the mounting inflation and competition it becomes very challenging for the educational institutions to sustain teachers. These influencing factors enable teachers to expect and demand promotion and raise in salary. Therefore, it can be seen in the data that the promotion has appeared third most important factor that influences teachers' job satisfaction.

Another strong factor that predicts overall job satisfaction is coworkers. It is fundamental to have a workplace environment that is conducive and free from subjectivity. Moreover, the expectations of the employees from their coworkers play a key role in developing a workplace that reflects teamwork and harmony amongst the staff. Harmer and Findlay in their study have investigated on the workers as core determinants of the overall job satisfaction and have found positive significance and correlationfor the similar factors. Correspondingly, a few more research studies have quoted similar results and have paid emphasis on the workers' cooperation and its influence on job satisfaction. However, they have also indicated its negative influence on biased employment practices. Since, the coworkers while emergent to their relationship develops work covetousness additionally (Ducharme \& Martin, 2000; Reece \& Brandt, 1999 \& Vigoda, 2009).. In Pakistani context, empirical observation indicates a, trend of females opting for professions like teaching and especially young females selecting to teach young children. Moreover, in early childhood sections teachers are encouraged to work in pairs and in small groups for a single project.

The data revealed that the strongest predicting factor is supervision on job satisfaction in this study. Interestingly, it was evident in the research analysis that supervision plays a great role in job satisfaction of the teacher whereas, there had been suggestions about salary and pay as the being the leading predicating factors for job satisfaction.

Moreover, the findings of the study havediscovereda strong association between overall job satisfaction and its influencing facets., The findings showed a highly significant correlation of all the facets of JSS, Spector, "pay, promotion, Fringe benefits, contingent rewards, operating conditions, coworkers, nature of work and communication". The results of the study conveys insights and reflections for educational organizations to strive rigorously and pay attention to the needs of the teachers. Additionally, this carriesintellectual capacityfor the human resource department of the educational sectors to promote activities within the schools that facilitate capacity building of the staff in teambuilding, participation, and self-reflection amongst the teachers. Besides, head of the educational institutions can be groomed to cater to the needs of the teachers and provide adequate personal and professional support to the teachers. Lastly, capacity development sessions for administrators to work on the working environment and operating conditions of the schools.

There are a few limitations to this study. Firstly, the sample chosen for this study was limited and targeted on early childhood teachers from Karachi private schools. Hence, generalisation of the findings is limited to a similar context and comparable population. Despite the limitations, the study provided the grounds for the conclusion to be established and it can be concluded that provision of satisfying remuneration, promotions, incentives, relation with coworkers and quality of the supervision predict job satisfaction. Therefore, the findings of the study might be helpful to facilitate human resource management and teachers' appraisal for early childhood private schools.

\section{References}

[1] Adeyinka, T., Ayeni, C.O., Popoola, S.O. (2007). Work Motivation, Job Satisfaction, and Organizational Commitment of Library Personnel in Academic and Research Libraries: Nigeria.

[2] Akinboye, J.O.(2001). Executive behaviour battery. Ibadan: Stirling-Horden Publishers.

[3] Akintoye, I.R. (2000). The place of financial management in personnel psychology. A Paper 
[4] Allen, J. (2009). A sense of belonging: Sustaining and retaining new teachers. United Stated: Martha Drury Manufactured.

[5] Anastas, J. (1999). How does clinical supervision affect job satisfaction?. The clinicalsupervisor.56 (2).

[6] Darling-Hammond, L. \& Sykes, G. (2003). Meeting the 'highly qualified teacher' challenge. $\quad$ Teacher Education in Practice. 4 (16), $331-354$.

[7] Dina Banerjee, Carolyn C. Perrucci (2010), Job satisfaction: Impact of gender, race, workerqualifications, and work context, in Christine L. Williams, Kirsten Dellinger (ed.) Gender and Sexuality in the Workplace, 20, 39-58.

[8] Durchame, L. J., \& Martin, J. K. (2002). Unrewarding work, coworker support, and job satisfaction. Work and Occupation,. 27(2), $223-243$.

[9] Ferguson, K., Frost, L., \& Hall, D. (2012). Predicting teacher anxiety, depression, and job satisfaction. (ed.1, Vol.8). Journal of teaching and learning.

[10] Gawel, Joseph E. (1997). Herzberg's theory of motivation and maslow's hierarchy of needs.Practical Assessment, Research \& Evaluation, 5(11). Retrieved May 15, 2012 fromhttp://PAREonline.net/getvn.asp?v=5\&n=11 .

[11] Gill, S., \& Ahmed, K. (n.d.). Job satisfaction among pakistani teachers,”. (Master's thesis, international Islamic University, Proceedings 2nd CBRC, Lahore, Pakistan, Islamabad).

[12] Graffin, M., Patterson, M., \& West, M. (2001). Job satisfaction and team work: The role supervisor support. Journal of organizational behaviour, $22,537-550$.

[13] Hammermesh, D. H. (2001). The changing distribution of job satisfaction.The Journal of Human Resources, 36 (1), $1-30$.

[14] Harmer, R. J., \& Findlay, B. M. (2005). The effect of workplace relationships on employee job satisfaction for. Paper presented at the 5th Annual Conference of the APS on the Psychology of Relationships Interest Group 2005.

[15] Khan, T. (n.d.). Teacher job satisfaction and incentive: A case study of Pakistan.. Unpublished manuscript, Pakistan. Retrieved from http://www.eldis.org/vfile/upload/1/document/0709/Teacher_motivation_Pakistan.pdf

[16] Kim, I. \& Loadman, W. E. (1994). Predicting Teacher Stress. The Ohio State University. Retrieved October 1, 2007, from the ERIC database. (ERIC Document Reproduction Service No. ED283707).

[17] Kosteas, V. D. Job satisfaction and promotions . Cleveland State University : OH.

[18] Kosteas, V. D. (2009). Job level changes and wage growth.International Journal of Manpower, 30 (3), $269-284$.

[19] Latif, K., Shahid, M.N., Sohail, N. \& Shahbaz, M. (2011). Job Satisfaction among Public and Private College Teachers of District Faisalabad, Pakistan: A Comparative Analysis. Interdisciplinary Journal of Contemporary Research in Business,3(8), 235.

[20] Loeb, S., Darling-Hammond, L., \& Luczak, J. (2005). How teaching conditions predict teacherturnover in California schools. Peabody Journal of Education. 80 (3), 44 -70.

[21] Long, A. (2005). Happily ever after? a study of job satisfaction in Australia. The Economic Record, 81 (225), 303 - 321.

[22] Opkara, J. O. (2002). The impact of salary differential on managerial job satisfaction: A study of the gender gap and its implications for management education and practice in adeveloping economy. The journal of Business in Developing Nations, 65 -92 .

[23] Reece, B. L., \& Brandt, R. (1999). Effective human relations in organizations (7th ed.). Boston, MA: Houghton Mifflin Co.

[24] Sargent, T., \& Hannumy, E. (2005). Keeping teachers happy: Job. Pennsylvania : University of Pennsylvania

[25] Spector, P. E. (1985). Measurement of human service staff satisfaction: Development of the job satisfaction survey.American Journal of Community Psychology, (13), 693 - 713

[26] Stutzer, A. (2004). The role of income aspirations in individual happiness . Journal of Economic Behavior and Organization, 54 , $89-109$.

[27] Vigoda, E. (2002). Stress-related aftermaths to workplace politics: the relationships among politics, job distress, and aggressive behavior in organizations.Journal of OrganizationalBehaviour, 23, $571-591$.

[28] Wallace, T. (2005). Factors influencing teacher job satisfaction and their alignment with current district practices in a rural school district . United States: ProQuest LLC.

\section{Author's Note}

Shelina Bhamani is a faculty and M.Phil. Scholar at the Institute of Business Management, Pakistan.Shelina's major areas of interest lie in early childhood development and teacher education. This research was supported in part by grants from Institute of Business Management, Pakistan and from the Cupola Foundation. I would also like to acknowledge the supervisory support given by Prof. Dr. Nasreen Hussain, Dr. Nadia Ayub, Ms.Shamira Bhamani and Mr. Nooruddin.S.Bhamani.Corresponding concerning this article should be addressed to Shelina Bhamani, Institute of Business Management, and Karachi.

Demographic of the Study Participants

Table 1

\begin{tabular}{llllll} 
Categories & Variables & N & M & S.D & S.E \\
\hline \multirow{2}{*}{ Qualification } & Bachelors & 93 & 139.1 & 17.2 & 1.8 \\
& & & & & \\
& Masters & 40 & 138.5 & 16.3 & 2.6 \\
\multirow{2}{*}{ Salary } & Below 20k & 95 & 138.0 & 17.1 & 1.8 \\
& Above 20k & 38 & 141.0 & 16.2 & 2.6 \\
& & & & & \\
\hline
\end{tabular}


Table 2

Factor Loading of the Nine Facets of Job Satisfaction

\begin{tabular}{ll}
\hline Variables/Facets & Factor \\
\hline Operating Conditions & .264 \\
Communication & .351 \\
Fringe Benefits & .445 \\
Pay & .464 \\
Nature of Work & .465 \\
Contingent Rewards & .493 \\
Promotion & .527 \\
Coworkers & .543 \\
Supervision & .638 \\
\hline
\end{tabular}

Table 3

T-Test Analysis of Demographic Variables

\begin{tabular}{|c|c|c|c|c|c|c|c|c|}
\hline Categories & Variables & $\mathbf{N}$ & M & S.D. & S.E & df & $\mathbf{t}$ & $\begin{array}{l}\text { Sig.(two } \\
\text { tailed) }\end{array}$ \\
\hline \multirow{2}{*}{ Qualification } & Bachelors & 93 & 139.1 & 17.2 & 1.8 & \multirow{2}{*}{131} & \multirow{2}{*}{.173} & \multirow{2}{*}{.863} \\
\hline & Masters & 40 & 138.5 & 16.3 & 2.6 & & & \\
\hline \multirow{2}{*}{ Salary } & Below 20k & 95 & 138.0 & 17.1 & 1.8 & \multirow{2}{*}{131} & \multirow{2}{*}{-.925} & \multirow{2}{*}{.357} \\
\hline & Above $20 \mathrm{k}$ & 38 & 1410 & 162 & 26 & & & \\
\hline
\end{tabular}

Table 4

Correlation of Overall Satisfaction with Nine Facets of Job Satisfaction

\begin{tabular}{lllll}
\hline Variables/Facets & M & SD & r & $\begin{array}{l}\text { Sig.(two } \\
\text { tailed) }\end{array}$ \\
\hline Pay & 14.1 & 3.5 & $.552^{* *}$ & .000 \\
Promotion & 14.4 & 3.5 & $.411^{* *}$ & .000 \\
Supervision & 18.2 & 3.6 & $.687^{* *}$ & .000 \\
Fringe Benefits & 13.8 & 3.4 & $.571^{* *}$ & .000 \\
Contingent Rewards & 14.5 & 3.9 & $.655^{* *}$ & .000 \\
Operating Conditions & 11.6 & 3.0 & $.424^{* *}$ & .000 \\
Coworkers & 18.1 & 3.2 & $.462^{* *}$ & .000 \\
Nature of Work & 19.1 & 3.6 & $.601^{* *}$ & .000 \\
Communication & 15.3 & 2.9 & $.557^{* *}$ & .000 \\
\hline
\end{tabular}

** Shows Significance

* N: 133 